\title{
Alberto del Campo Tejedor, Burla burlando. Las diversiones de los universitarios en el siglo XVI, Salamanca, Amarante, 2019, 169 pp. ISBN: 978-84-949946-0-91
}

\section{Ignacio Arellano}

ORCID: http://orcid.org/0000-0002-3386-3668

Universidad de Navarra, GRISO

ESPAÑA

iarellano@unav.es

[Hipogrifo, (issn: 2328-1308), 8.1, 2020, pp. 653-656]

Recibido: 09-09-2019 / Aceptado: 08-11-2019

DOI: http://dx.doi.org/10.13035/H.2020.08.01.44

Hay un linaje de reseñas que solicitan del autor reseñado lo que este no quiso hacer en su libro. Reclaman cosas que el reseñista habría querido hacer si hubiera escrito el libro que no escribió, proponen una nueva estructura, nuevos capítulos, otros textos, un enfoque distinto, etc., en suma, otro libro.

Para no incurrir en ese tipo de arbitrariedad debe situarse este libro de Alberto del Campo en el ámbito en el que lo ha concebido su autor, que es un nivel no demasiado especialista, dirigido a un público culto pero no necesariamente preocupado por demasiadas profundidades teóricas y que puede leer con gusto y utilidad estas páginas, muy bien documentadas y muy bien escritas por alguien sin duda experto en este mundo de las diversiones y entretenimientos del XVI, que tienen por cierto relación con el mundo jocoso anterior (antigüedad clásica y Edad Media) y también con el posterior: sin duda con el siglo XVII, pero incluso, como en varias ocasiones subraya del Campo, con prácticas que llegan hasta el siglo XXI, como las repentizaciones o pullas en la vendimia documentadas en la Alpujarra.

El tema de la burla y la risa fue siempre uno de los más complicados de abordar para teóricos y analistas de la obra literaria y de las prácticas sociales. Parece haber en la bibliografía reciente un renovado interés por este terreno, según evi-

1. Esta reseña forma parte de las actividades del Proyecto FFI2017-82532-P, Identidades y alteridades. La burla como diversión y arma social en la literatura y cultura del Siglo de Oro, del Ministerio de Ciencia, Innovación y Universidades-Agencia Estatal de Investigación del Gobierno de España (MICINN/AEI/ FEDER, UE) 
dencian algunas publicaciones como Demócrito áureo Los códigos de la risa en el Siglo de Oro, ed. Ignacio Arellano y Victoriano Roncero, Sevilla, Renacimiento, 2006; Linda burla. La risa en el teatro clásico, Cuadernos de teatro clásico, 33, 2019; el volumen 185 de la revista Hispanófila (2019) dedicado a Burlas y veras en el Siglo de Oro; otro monográfico de la revista Ínsula (873, 2019 Burla, burladores y burlados en la literatura hispánica), etc. Alberto del Campo ha contribuido durante años a los estudios en este ámbito (remito a la bibliografía final de este volumen que reseño, donde se recogen numerosos trabajos suyos sobre poesía de repente, la risa de las fiestas navideñas y carnaval, bufones, diversiones burlescas clericales, etc.), y ahora ofrece una agradable y solvente introducción a las diversiones de estudiantes (y otras gentes) en el siglo XVI.

Me parece excelente idea haber tomado como guía los Coloquios de Palatino y Pinciano de Arce de Otálora, obra espléndida, verdadera enciclopedia de estas diversiones (y muchas más cosas) y de lectura más llevadera que otras más o menos semejantes, como la Agricultura cristiana del padre Pineda, bastante más difícil de transitar. Desde el punto de vista de las diversiones Arce de Otálora resulta demás una fuente de información privilegiada por el mismo enfoque de los Coloquios, que se sitúan en tiempo de vacaciones dedicado al descanso y el entretenimiento que sirvan de contrapeso a las tareas pesadas de la vida estudiantil, las penalidades materiales y los esfuerzos intelectuales del resto del año.

Se trata, por tanto, en suma, de una aportación bien planteada, escrita con conocimiento de la materia y - no menos de elogiar-escrita con claridad y amenidad.

El objetivo de llevar a cabo la «contextualización histórica y socioantropológica de estas prácticas burlescas... contextualizando los testimonios literarios jocosos con las prácticas de su época» (pp. 16-17) es irreprochable, aunque presenta obstáculos que no parecen fáciles de vencer, y quizá requieran otro tipo de perspectivas teóricas (que no son, ya se ha apuntado, el objetivo de del Campo en esta ocasión).

En este sentido el autor repasa en diferentes capítulos breves el tiempo de fiestas (cap. 2), el concepto de eutrapelia (cap. 3), prácticas festivas como el obispillo (cap. 4), las misas nuevas y vejámenes de grado (cap. 5), el coplear de repente (cap. 6), juegos de latín macarrónico (cap. 7), diversiones del loquear (cap. 8), la sátira (cap. 9), la vida apicarada de los estudiantes (cap. 10), la moderación de la risa (cap. 11), la burla villana (cap. 12), para concluir con el comentario del humor de Arce de Otálora (cap. 13).

Al hilo de esta ordenación se van insertando numerosos cuentecillos, descripciones de diversiones varias, apoyando los textos de Arce de Otálora con otros repertorios como la Floresta española de Santa Cruz, el Libro de chistes de Pinedo, las apotegmas de Rufo, el Tesoro de Covarrubias y otros.

La lectura de estas páginas plantea inevitablemente algunas preguntas, cuya respuesta no están obligadas a dar en el marco de la perspectiva de este volumen. Las consideraciones que siguen, por tanto, no afectan directamente al libro de del Campo en cuanto que el autor no ha pretendido abordar estas cuestiones teóricoprácticas, pero quizá puedan contribuir a nuevos planteamientos en otro tipo de 
enfoques o niveles de estudio. Habría que enfrentarse, por ejemplo, a las implicaciones terminológicas que podría sugerir el mismo título. En efecto, en muchas ocasiones se considera el hablar de burlas o el término burlas en la contraposición burlas y veras, como sinónimo de burla en el sentido 'chasco, ridiculización, escarnio'. Semejante identificación atraída por el vocablo oculta y falsea aspectos esenciales de cada área: pues hablar de burlas y burlar, en muchos contextos podría traducirse como 'bromear', tomarse en broma y a la ligera una cosa, mientras que la burla como escarnio es siempre una agresión. Habría que definir cuidadosamente qué significa burla en un determinado contexto. Diversión (que aparece en el título del libro de del Capo) no es lo mismo que burla. A lo largo del estudio alternan por ejemplo -al parecer en nivel de equivalencia-diversiones como la pelota, el saltar, bailar, los bolos, el juego de la argolla, etc. (p. 34) que ningún riesgo ofrecen desde el concepto de eutrapelia ('diversión benévola') con ejemplos de chascos cuyo nivel de agresión es difícil de controlar porque dependen en buena parte de la reacción -incontrolable e imprevisible por definición- el sujeto víctima. La asociación, por ejemplo, de alegría, risa y burla, que asoma en varias ocasiones, no es de ningún modo inmediata. Valga recordar el prólogo de Quevedo a la Hora de todos (manuscrito Frías) donde se refiere a la risa que provoca su obra, que compara con la risa de las cosquillas porque hace reír con enfado y desesperación: muchas burlas son peligrosas porque pueden tocar al honor o dignidad de un sujeto, lo que no ocurre con diversiones como el juego o los bailes de las mozas cuyos peligros proceden de otros motivos. Es significativo en este sentido el ejemplo de Jesucristo que comenta el personaje Hedonius de Erasmo rechazando la idea de algunos que conciben a Cristo como triste y melancólico. Pues en efecto, no hay que suponer que el contrario de un Cristo melancólico sea un Cristo burlón o risueño -como parece sugerir Hedonius o podría desprenderse del comentario de del Campo-, porque los conceptos de lo agradable, alegría, placer, gozo y otros semejantes no se identifican con la risa y la burla, ya que la risa, según ideas clásicas y vigentes hasta el Siglo de Oro por lo menos, procede de la turpitudo et deformitas, lo que es ajeno completamente a Cristo y ajeno a la mirada con la que Cristo ve a los demás. Por eso se ha pintado a Cristo como agelastos, que no ríe, y por eso - principalmente por eso, no solo por eso - la enemiga de la Iglesia contra la risa y la burla, porque estas requieren una víctima y eso va contra la caridad. La burla puede ser enemiga de la diversión y del goce, la risa puede ser enemiga de la alegría. La alegría no implica necesariamente la risa; la sensación de gozo, placer, júbilo, felicidad, o contento mantiene con la risa una relación mucho más conflictiva de lo que a menudo se considera.

Pero no es momento de indagar en los vastos problemas en torno a las dimensiones teóricas, literarias y sociales de la risa, la burla y la diversión.

Indicaré, para terminar, que sorprende un poco la ausencia de un texto tan importante como el Buscón, muy poco explotado (solo citado una vez, si no me equivoco, pero olvidado en el comentario de las nevadas o esputos con los que reciben a los estudiantes novatos y que da pie a uno de los episodios más grotescos de las aventuras de don Pablos, y tampoco aducido en el chiste estudiantil del garbanzo náufrago ni a propósito de las miserias del pupilaje que se documentan con otros 
textos mucho menos relevantes como la Farsa salamantina de Bartolomé Palau). Pero no deja de ser un derecho del autor elegir sus ejemplos.

En conjunto Burla burlando es un libro cuya lectura cumple con creces los objetivos de enseñar y entretener, por el que procede felicitar al autor que añade con él otra apreciable contribución a las numerosas que ha publicado sobre el mundo de la diversiones, juegos y risa en la literatura y la sociedad y una aportación relevante para el mejor conocimiento de un texto tan valioso como los Coloquios de Arce de Otálora. 